\title{
Forest Re-seen: From the Metropolis to the Wilderness
}

\author{
Yan Wang Preston
}

A three-hundred-year old tree standing alone in a deserted land, uprooted away from home. Powerful grey trunks, dark red soil, no leaf, no life.

A one-year 'old tree', made up with fifteen young trees bandaged together in shining golden fabric. Thick trunk, hollow inside.

An entire quarry covered by suffocating green plastic netting. A green heaven. A green hell. An entire mountain eaten away by shovels and diggers, then dressed up with trees and flowers. A new adventure playground. A new natural grandeur.

Whose forest?

And what wilderness?

This paper is written from the perspective of a practising British-Chinese artist whose primary source of information comes from an embodied, yet critical observation of the physical world. The multisensorial and social experiences, as well as the photographs produced within the process, supply foundational materials for photo books, exhibitions, texts and other forms of publications. Colours, compositions and moods are as important as text while ambiguity is as valid as clarity. Emotions and feelings often lead the way for making the visual work, yet critical reflection and contextualisation are equally important for providing a crucial framework. And such framework brings in relevant information from both the Western context and China, since they serve as a reference for each other.

The paper will start with a critical review of my eight-year photographic project, Forest (2010-2017), which investigated the complexities and politics of nature restoration projects in two new Chinese cities. Using repeat photography and visual storytelling as the key methods, the project followed the developments of transplanted old trees in their new urban home before documenting some questionable landscapes of ecology recovery projects at disused industrial sites. The primary output is an edited sequence of sixty-five images with accompanying text in the format of a photo book, forming an emotional as well as intellectual discussion on the complex conditions of constructed urban nature in China. 
The paper will then extend the notion of the constructed nature to an international context, within the global conservation efforts of re-naturalisation and rewilding before highlighting the latter as the subject of discussion here. Drawing from empirical and theoretical studies, the inherent contradictions and politics of rewilding in the post-wild world will be analysed. Meanwhile, the goal of many rewilding projects - the highly managed, artificial neowilderness - will be brought into attention as a physical space to be investigated by landscape photographers.

The third section of the paper will return to its roots as practice-based research and try to understand the neo-wilderness from the perspectives of landscape aesthetic traditions of both the West and China. Such aesthetic traditions reflect the perceived relationship between people and nature, which is in need of a critical review during the current age of environmental and climate change. The discussion here is an early attempt to place China's desire to be an eco-civilisation into a field that is not defined by nations, but by our collective perceptions towards human's relationship with nature in the industrial and technological societies. The paper will conclude by asking instead of answering questions: what is nature to us now and what landscape aesthetics do we have to depict it with? To what extent do artistic have responsibility in shaping societal understanding of some of the most fundamental yet urgent issues of our time? And finally, what can be an appropriate pictorial understanding of the neo-wilderness - the constructed, wild landscapes? 
Part I: The golden tree: on the nature of nature in contemporary Chinese cities

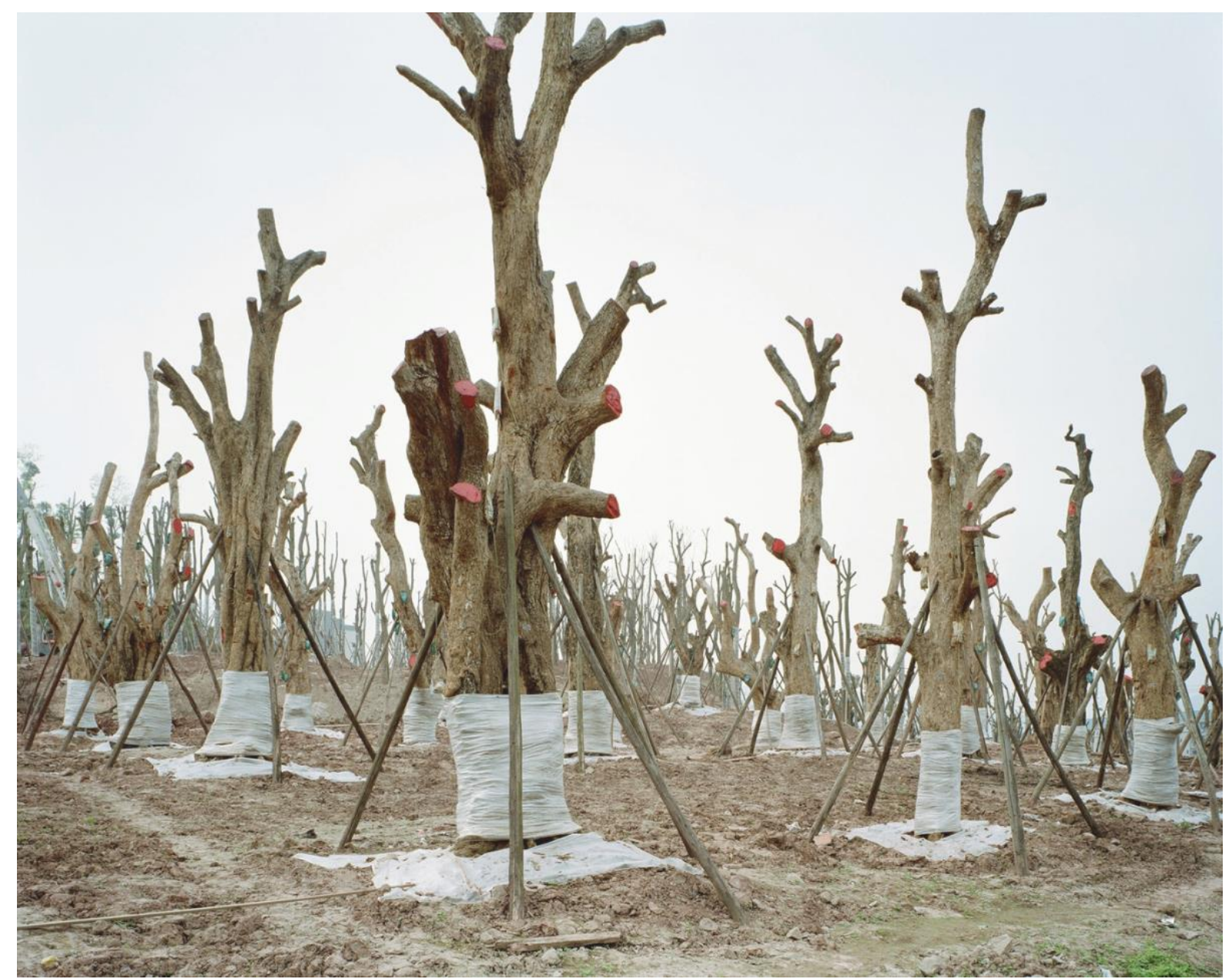

Plate 1 Longan woodland, University City, Chongqing, China, 2017. CYan Wang Preston, Forest series.

In December 1978, China began its new policy of economic reform. The effect of this has been witnessed by most of us. Responding to the country's rapid changes, photographers have mounted waves of investigation, intensified since the Three Gorges Dam construction began in 1994. The Dam serves not only as a physical milestone for China's technological advancement, but also as a political landmark re-enforcing Chinese government's rights to rule --- the ability to control water and floods has always been seen as the passage to the throne in Chinese history, as told in the semi-mythic story of Da Yu Zhi Shui and in the mythic power of long, the Chinese dragon (Lewis, 2006).

The controversies over the Three Gorges Dam within and outside of China reflect the conflict between preservation and development. Such preservation lies not only in the natural environment, but also in a land rich with history and iconic landscapes. The irreversible 
flooding of such historical land violently dismisses a cultural memory and a sense of identity embedded in the landscapes (Wu, 2008; Jiang, 2015).

Photographers swarmed to the Three Gorges Dam and the Yangtze River, as well as China's other great rivers and the cities along them. Western photographers appear to pay more attention towards the structural intensity of China's urbanisation and industrialisation. ${ }^{1}$ Birdeye views of wide city landscapes, often emphasising on the gigantic scales, are produced with a documentary precision and a topographic detachment. For them, nature in China is a quantifiable, physical existence and an environmental victim. Their work is primarily disseminated within the western audiences who are more aware (than the Chinese audiences) of the debates around the global environmental crisis and climate change. The photographs from China function as an evidence of an unsustainable development with potentially disastrous environmental effects. Such environmental concerns are often complicated with an implied criticism on China's political system, which is to be blamed for the country's problems. For example, Nadav Kander (2010), a London-based photographer who won the Prix Pictet award with his project Yangtze, The Long River, states that 'common man has little say in China's progression and this smallness of the individual is alluded to in the work.'2

Chinese photographers respond to their country's development with a richer emotional undertone $^{3}$. Expansive river scenes and cityscapes are observed from a closer distance while bird-eyes views are rarer. Objects in the foreground are often rich in symbolic meanings and cultural associations, which are readily appreciated by the readers knowledgeable of Chinese culture. Instead of the detached, topographic views, they are more prone to adopt an aesthetic akin to Shanshui - the Chinese traditional landscape paintings. Their pictures are frequently characterised with a thin layer of mist, in long or vertical scroll format, or converted in greyscale with rich mid-tones but no highlights or shadows, echoing the rich tonal subtlety of

\footnotetext{
${ }^{1}$ Examples of these western photographers include Edward Burtynsky (2005), Michael Wolf (2012), Nadav Kander (2010), Peter Bialobrzeski (2009) and Ferit Kuyas (2009).

${ }^{2}$ This quote is taken from Kander's statement for his project Yangtze, The Long River, published on his website: http://www.nadavkander.com/works-in-series/yangtze-the-long-river/single\#2. Accessed on 12 ${ }^{\text {th }}$ October 2012.

${ }^{3}$ There is an abundance of exemplary Chinese photographers and artists: Zhuang Hui, Xiao Xuan'an, Yan Changjiang, Li Ming, Zen Hang, Li Zhaohui, Zhang Kechun (2014) and Yang Yongliang (2011).
} 
an ink and water painting on rice paper. A sense of longing for an imagined traditional land, as portrayed in Shanshui, and a loss of a cultural identity associated with that land, can be felt in these pictures. For the Chinese photographers, nature appears to be more spiritual than physical. It is an imagined and mythic homeland. Concerns over the environment and sustainability are equal to, if not often shadowed by, the concerns over an aesthetic identity one that is attached to a mythical and harmonic world constructed in Shanshui paintings.

Situated within the above photographic context, the Forest project critically responds towards the rapid urbanisation of China and attempts to understand some of its mechanism by telling visual stories. The project began with strong emotions felt towards one form of non-human life within questionable urban landscapes - transplanted old trees in new cities born out of total design. Among the concrete forest of a city with thirty million people - Chongqing, rows and patches of bare, old trees stood motionlessly while their crowns had been violently removed. Their amputated branches, often painted red for protection, literally looked bloody. (See Plate 1 as an example.) Meanwhile, they were always placed in shiny new places, often still under construction: shopping malls, property development zones, new roads, new bridges, new parks, new hotels.

The visible trauma and the conflict between the old and the new prompted questions. What was happening? Where did the trees come from? Who was benefiting from the tree dealing business? Would the trees survive? I began to photograph intuitively, making formal compositions of the rigid urban design with the organic form of the trees, emphasizing the unnaturalness of such constructed nature. There were often no other elements in the landscape, making visible the trees' isolation from each other and from their established homeland. The light was flat, and the colours limited to mainly grey and green. The mood was heavy, painful but restrained. The beauty and brutality of these tree sculptures were acknowledged simultaneously.

The direct cause for such bizarre treescape was easy to identify. In order to make their environment greener and more suitable for living, many expanding Chinese cities were buying mature trees to 'build' forests instead of growing young trees. Although the phenomenon was popular in most of the cities along the Yangtze River, Chongqing had a particular intense phase of transplanting around 2010, due to the government's vision of building the city towards 'five ideals. 'A Forest City' was one of the ideals. As China's 
youngest municipal city, the city's intense urbanisation was coupled with its mass tree transplantation. I decided to concentrate on Chongqing alone, since the city would provide enough materials for the project's research and development.

Admittedly, it was the pain I felt when looking at the displaced, and often misplaced, old trees that prompted the project. Why so much compassion towards a few trees? In other words: why are trees attractive to city dwellers anyway? For this the American biologist E.O. Wilson (1990) provides an explanation as biophilia. He argues that humans have an inborn love towards nature, and life, which are the definition of home. Evolution over millions of years has written such idea of home into our genetic code, in which trees are just as important and necessary as water to make a place liveable, and, beautiful. Perhaps this explains why in every model displayed at the property sales offices in Chongqing, there will be a tree next to the apartment blocks. Without a tree, a home is not a home. The love of home extends to the love of trees, and with love, there is empathy and compassion. An injured and displaced tree can therefore evoke an emotion of pain and sympathy.

Images from this initial phase of the Forest project were made to express emotions and to raise questions. Pinpointing the period immediately after a tree's transplantation as the starting point and the new urban area as the focus, the project then employed repeat photography as one of its key methods in order to deepen the investigation. Certain trees, woodlands and areas were photographed repeatedly over the course of seven years from comparable angles and weather conditions. To photograph repeatedly is to have a dialogue with the history of the specific subject matter (Martinsson, 2015). In the short duration of the Forest project, repeat photography has been a powerful tool to keep the photographer's prejudice in check, since the unfolding of the story is out of the photographer's control. With such methodology, the project collected key case studies that formed the main storyline. Among these, Frank is a representative.

\section{Story I: Frank}

Frank's story started in March 2013, when the 300-year old daqing tree (Ficus hookeriana Corner) was still standing at its home of a traditional Bai village. However, a Yangtze River dam nearby was soon to flood the area. As seen in a line of red propaganda slogan underneath Frank's canopy, the villagers were encouraged to move out early, so that they could resettle early and to get rich early. Three months later, the village was flattened, and 
Frank was sold to a five-star hotel one hundred kilometres away. It had lost its impressive crown and was transplanted onto a desert looking land, in a small pile of soil as red as blood. According to its village people, Frank and three other century-old trees were sold together for 12,000 dollars. Each family had a share of the money, which would contribute to the cost of building their new homes. Four years later, in 2017, the surrounding city had been built up, yet Frank had gone down. It had died two years ago. Only the mound of red soil that it once stood in remained.

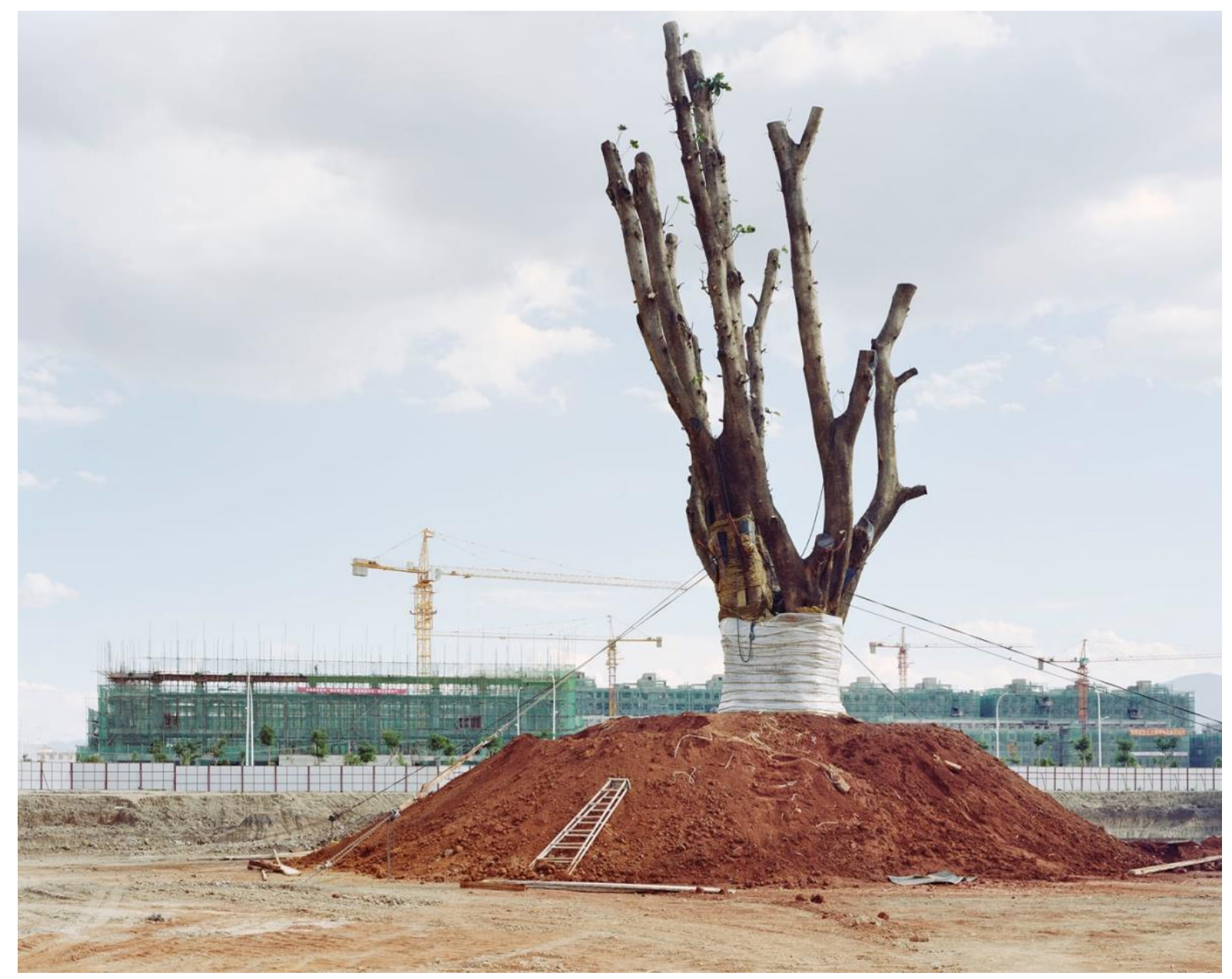

Plate 2 Frank, June 2013. CYan Wang Preston, Forest series.

As commented by the English curator Thomas Dukes (2020), "This story starts at home, moves through development, and results in the failure of transplanting the tree. An incredibly neat tragedy." In this tragedy, Frank changed, from part of someone's homeland, to a commodity. A trophy, to increase the attraction of a luxury lifestyle. The storytelling strategy employed in Forest can be largely summarised in the case of Frank. A sequence of three images taken in March 2013 before the transplantation, in June 2013 immediately after the 
transplantation, and in November 2017 as a result of the transplantation, serve as a visual evidence of the story while crucial information untold in the pictures is supplied as text, in the form of a factual, yet emotionally-moving narrative.

Frank's story is one of the pinnacles in the Forest project. It asks questions about the value of not only trees, but old trees, in our landscape. Jiang Jiehong (2015) states that China's current era is one without memories. It appears that, although an entire city can be erased during the urban renew and expansion, some elements of it, for example, od trees, can be rescued or recycled before total destruction. And wherever they go, they take their memories with them. Older trees fetch higher prices when sold to cities. Is it because that, to people living in an urban environment built on a complete erasure of the past, memories of a homeland, as embodied in an old tree, are still important and valuable? Yet a displaced, dying old tree is also a living manifestation of a violent disrespect towards history and traditions. In a city among trams, taxies and cars, these transplanted old trees can serve as a reminder of such painful conflicts within our desires. 


\section{Story II: Goldie}

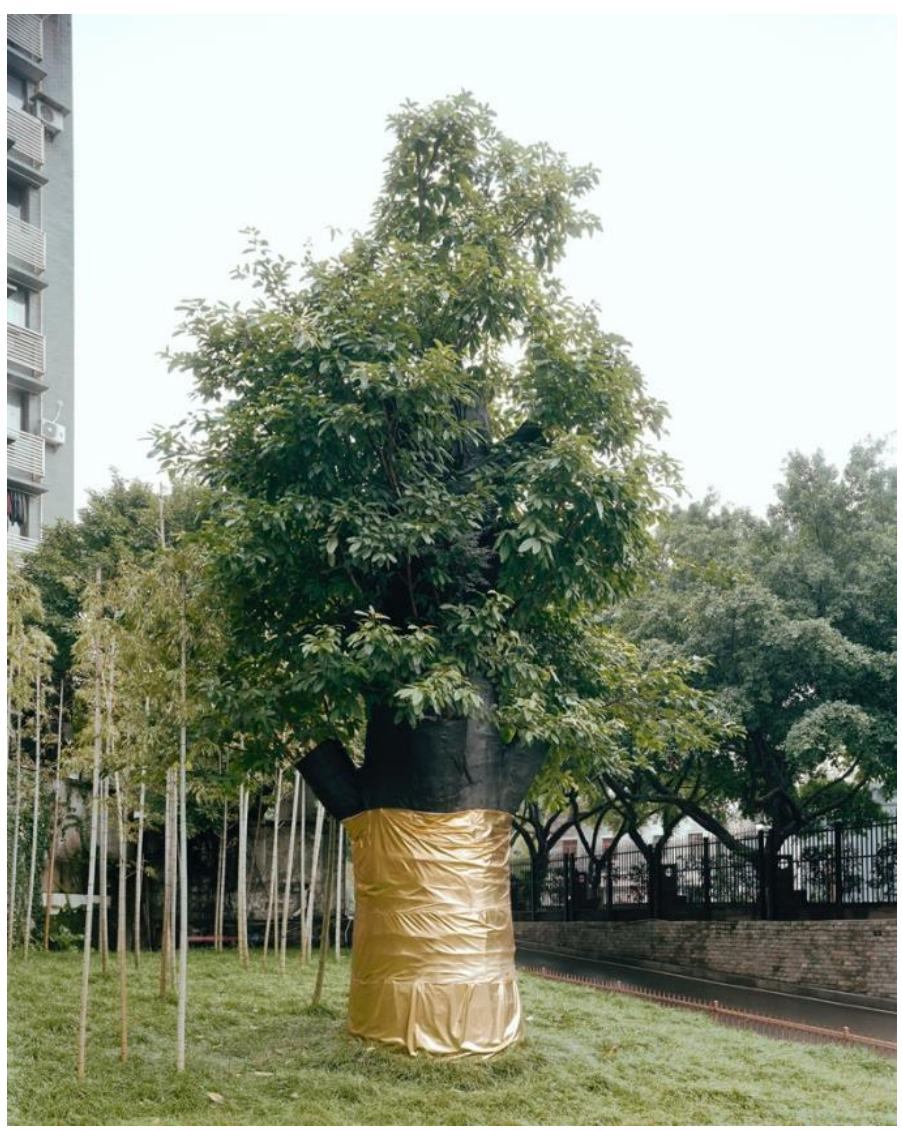

Plate 3 Goldie, 2017. CYan Wang Preston, Forest series.

Different from Frank, Goldie (Plate 3) was a fake old tree. It was made up with fifteen young trees, a flower tree, and some water pipes. They were bandaged together and planted in the courtyard of a four-star hotel that desired aged trees but did not want to pay for them. Golden fabric was wrapped around the new conglomerate to give it a deceptively old look. If everything went well, in another two years' time, the roots of these young trees would join together and they would become one grand 'old' tree, Goldie ${ }^{4}$.

Goldie takes the story of the transplanted old trees in the Forest project over and above its logic climax while making visible the nature of such constructed urban nature in contemporary China. The American geographer J.B.Jackson (1984) writes on the differences between the political and the vernacular landscapes. The former includes mainly man-made structures primarily serving political functions such as boundaries, roads, public spaces and monuments. They are built to impress and are more visible. Landscapes formed by the displaced old trees, of Frank and Goldie, belong to such political landscapes. Instead of

\footnotetext{
${ }^{4}$ I named these trees: Frank and Goldie.
} 
nature, the trees are in fact political monuments, reflecting the ideology of a rapid economic growth instead of a more sustainable development. The desire for gold is hidden behind the colour green, the symbol of life. Until now, the Forest project is about disharmony, about a total design for living so absolute that one is ready to kill nature for it.

\section{Story III: The Park of Geese on the Rock}

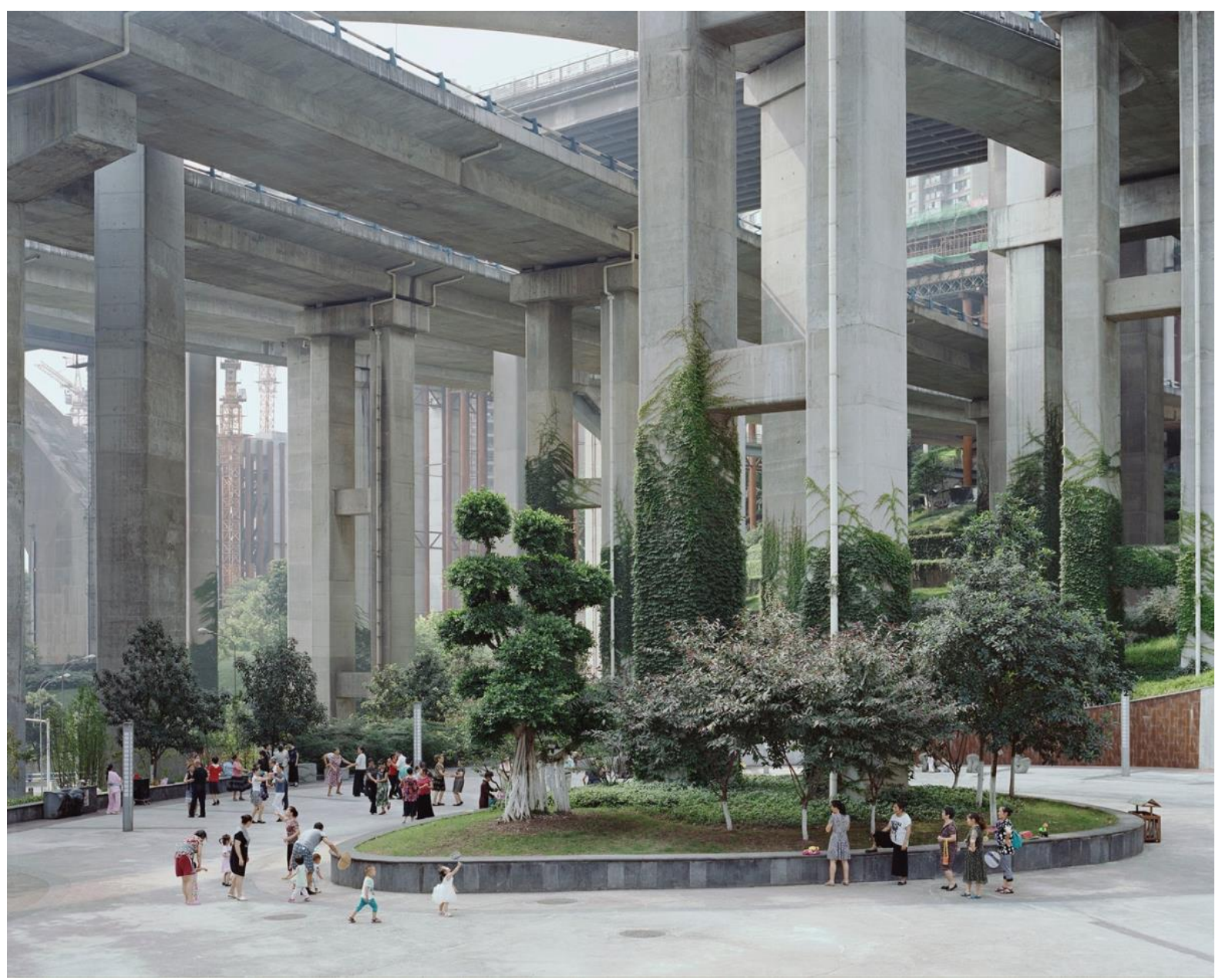

Plate 4 Egongyan Park, Chongqing, China, 2017. CYan Wang Preston, Forest series.

The area around the Egongyan Yangtze River Bridge in Chongqing has everything: the iconic Yangtze River, the impressive suspension bridge, the new city with its concrete forest, a park on the hill underneath the bridge, and transplanted old trees in the park. It may even have a more 'natural' history, since its name indicates a possible scene in the past: a group of geese standing on the rocks. For the Forest project, the area was photographed in four separate sessions in 2011, 2012, 2014 and 2017. From faceless concrete skeletons and isolated alien trees, the area was gradually inhabited by new residents, who soon established their daily 
routines. Before 9 am the streets were lined up with breakfast stalls, steaming with dumplings and soymilk. From 10am to 11:30am, dancers would gather in the park and practice their fusion routines with red and green fans. Little children run around noisily in their princess dresses, chasing bubbles around the carefully designed gardens. Their grandmothers watched and gossiped. Meanwhile, the transplanted old trees had established themselves quietly and the ivy had almost climbed up the entire concreate columns. It appears that, in the concrete under passage of Egongyan Park, a brutal beginning of transplantation, displacement and migration was slowing evolving into life and its daily chores. The children will remember this as their homeland, with the trees already in place since their memory begins.

The development of Egongyan Park area pushed the Forest project into new directions. On the level of visual strategy, I began to build a tableau style storytelling aesthetic on top of a consistent topographic depiction, in which human figures were carefully arranged into a precise landscape composition. For the storyline, the city was developing from a tragedy to almost a comedy. From a totally designed political landscape that reflects only the ideology of modernisation, the city was beginning to grow into a vernacular homeland. The gradual unfolding of the tree stories slowly became a human story, the pursue for nature tells us more about human nature.

Acting as a tree spotter, I walked through the dense layers of the urban forest, watched, listened, smelt, touched and discovered, reflected and photographed. Beginning from the individual trees, I gradually took in the wider cityscapes while embracing the new urban life. I saw that, often the new trees were taken for granted. And occasionally plastic trees would have more attention than organic ones. Sometimes the city scenes reminded me of terrors from other eras, with thousands of red flags waved at public squares while slogans are repeatedly shouted. Again, the transplanted old trees stood slightly and witnessed this new chapter in the city, while scar tissues slowly grew around the nails and ropes left on their trucks from the transplantation process. Despite a traumatic past, the new nature had settled into the city.

The Forest project completed at the moment when the totally designed urban landscape began to be over-grown by escaped plants. From a condemnation of urbanisation from an environmental ground, the project gradually accepted the urban as a possible homeland. Such observation anticipates Matthew Gandy's text on cities and the deep time (2018): 
'Judging from an eco-centric point of view, there is a pervasive trend of anti-urban and antimodern when critically reviewing the urban environment and urbanisation. However, the diverse cultures of nature encountered in cities problematise the meaning of ecological authenticity and attempts of landscape restoration raise questions about the temporal specificity of social-ecological relations...Cities can offer an alternative to dystopian stasis. We need an augmented conception of what the city is, what it can be, and how it relates to the wider political dynamics of the capitalist technosphere. An overemphasis on various forms of 'methodological globalism' elides the cultural and urbanisation and effectively overlooks the heterogenous socio-ecological textures of urban space.'

To summarise, the Forest project did not aim at developing photographic aesthetics or inventing new forms of photo books. Instead, it rests on contemporary environmental awareness and established, canonical aesthetics rooted in the New Topographics ${ }^{5}$, the documentary and the storytelling in order to communicate effectively. Although the subject matter may have great weight, the stories are told at a humane level with lightness.

What may set the Forest project apart from other photographic projects critically observing China's urbanising environment, is a standing point that refuses to make a judgement purely on an environmental ground. Instead, it opens up the complexities of urban nature and the culture around it while beginning to accept the urbanising China as a possible homeland. Although the project is based in China and made by a native Chinese artist, it intends to communicate with international audiences by not including overt Chinese symbolism and by focusing on a subject matter, trees, that transcends nations.

\footnotetext{
${ }^{5}$ See Part II for a detailed explanation on the New Topographics: Photographs of a Man-altered Landscapes exhibition and the aesthetics that it established for contemporary landscape photography.
} 


\section{Part II: Rewilding in the post-wild world}

Chongqing's vision of becoming a Forest City can be contextualised within China's central policy of building a green, circular and low-carbon eco-civilisation, which was gradually introduced and developed by Xi Jinping and the Chinese government since the early twentyfirst century before being written into Chinese constitution in $2018^{6}$. A new slogan in plain language - 'Green mountains and clean waters are golden mountains"7- is now painted at many disused quarries and mines that are going through gigantic re-naturalisation processes. Such policy demonstrates China's desire to join the global effort to reconcile with nature. It appears that after millions of years of mass landscape transformation caused by hunting, farming, deforestation, industrialisation, urbanisation and the climate change, many people, from policy makers to scientists and to citizens, are now critically re-examining our relationship to nature while trying to repair the damaged earth with (trans-)national as well as personal actions. Re-naturalisation, ecology restoration and rewilding are now some of the leading yet much contested efforts in global conservation. Having studied constructed natural environment in Chinese cities, I will now focus on rewilding and the wilderness constructed by it as the centre of my investigation, since the signs of complexity and contradictions are the most concentrated. Although it is beyond a visual researcher's capacity to comment on rewilding scientifically, I will attempt to understand it from an aesthetic point of view. But first of all, it is worth having an overview of rewilding and some of its politics.

Rewilding, as a nature conservation idea, was defined by the American biologist Soule in 1998 as an emphasis on 'the restoration and protection of big wilderness and wide-ranging, large animals - particularly carnivore.' (Soule, 2014:233). One successful example of rewilding has been the re-introduction of wolves to the Yellowstone National Park. The wolves hunted and agitated large herbivores, as a result the vegetation was protected, which in turn led to the recovery of riverbanks and a whole set of ecological cycle (Soule, 2014). Interestingly, the wolves may be helpful to restore the National Park's ecology, but they also propose danger to the cattle ranches just outside of the Park's boundary. For the farmers, such wilderness was not welcomed initially and must be kept within the park. The confrontation

\footnotetext{
${ }^{6}$ Details of the policy's development can be seen on http://politics.people.com.cn/n1/2019/0909/c42937331344147.html in Chinese. Published on 9 September 2019, accessed on 15 October 2019.

${ }^{7}$ The slogan in Chinese is 绿水青山就是金山银山.
} 
between the rewilders (and the wolfs) and the farmers clearly demonstrates that politics is at play here. Whose wilderness are we preserving? For whose benefits? The 'ideological commitment to preserve nature', its class-based and even imperially infected tendency, have been critically examined by scholars such as Katz (1998:69). Besides the politics, a play on words can be detected in the naming of such conservation action. The keystone carnivores are generalised as the 'wilderness', since these are the iconic symbols of the 'uncultivated and untamed' land. The intentionality and artificiality of such 'wilderness' indicate inherent contradictions. Using the Yellowstone National Park, Hawaii and other conserved 'pristine' areas as case studies, naturel writers such as Maris (2011) concisely state that the wildest landscapes on the Earth are precisely the most managed by human beings, since such wilderness cannot exist by itself.

Yet the call of the wilderness continues to intensify in the last twenty years with many adaptations. For example, in North America and Europe, one 'branch' of rewilding is to restore river ecology by removing disused river barriers. Such actions are to 'free' the rivers, as the organisation Dam Removal calls it ${ }^{8}$. Similar to 'rewilding', the term 'freeing' is a powerful metaphor which goes way beyond ecology. It is no surprise that Dam Removal and its associated organisations can seek public support by launching crowdfunding campaigns for their projects. A free smartphone application Barrier Tracker is also launched, so that people can spot river barriers and report them through the application. The public popularity of the 'freeing rivers' movement can confirm once again the mythical state of rivers perceived in human culture. As analysed by the historian Simon Schama (2004), inspired by the Nile and its annual floods, ancient human beings came to associate free-flowing rivers with the natural cycle of life. River obstacles such as dams and weirs therefore not only alter its ecosystem, but also interrupt its flow and fatally damage its mythical power held in our mind. Yet, such understanding is based on a relationship---an interaction between people, the river and the ecosystem connected them. The 'free' river is not external of human life.

In the Central Apennines, Italy, Marsican brown bears are carefully preserved, along with an

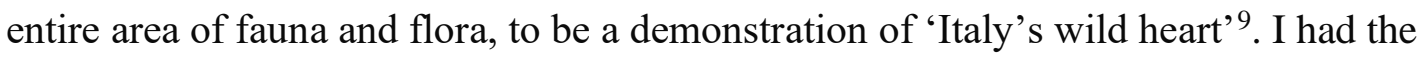

\footnotetext{
${ }^{8}$ An example of the 'freeing rivers' action can be seen on: https://www.damremoval.eu/freeing-of-hiitolanjokiriver/. (Accessed on 5 January 2020.) ${ }^{9}$ As described by Rewilding Europe on https://rewildingeurope.com/areas/central-apennines/. (Accessed on 6
June 2020.)
} 
opportunity to experience such wilderness during a guided eco-tour. But the pleasure did not come easily or cheaply. It involved thousands of miles of travelling and a small fortune to pay for the expenses, including a cooked meal with wine in a remote refuge, equipped with clean bed sheets and a shower. In other words, this wilderness somehow felt unnatural, tamed and costly. It may be beneficial in the long term for the preservation of biodiversity, as argued by conservationists. But it is also a luxury, only to be enjoyed by the few. Meanwhile, that the wilderness is now a tourist attraction suggests its alienation from human life. We no longer live with it. We can only go to peep at it as 'the other' occasionally.

Back to Britain, where wilderness has not been part of the traditional landscapes, rewilding is not only practiced by conservationists, but also entered the public consciousness in recent years, thanks to the promotion of some powerful writers. In 2013, the environmentalist and journalist George Monbiot's book Feral: rewilding the land, sea and human life passionately promotes rewilding as 'resisting the urge to control nature and allowing it to find its own way' (Monbiot, 2013:9). The finale of the book tells a story Monbiot's fishing trip, during which he was trapped in dangerous water and nearly failed to return home. With such close and life-threatening encounter with the wild nature, Monbiot declares that he has finally rewilded himself. Clearly Monbiot's advocacy on rewilding rests not only ecology or science, but also on his own romantic association with nature. He is part of the bourgeois class to whom nature is more imagined, represented and consumed than lived. But Monbiot is certainly not alone in this romantic pursue of an imagined, yet problematic wilderness. Books like his influenced the founding of Rewilding Britain, a charity dedicated to the subject in 2015, while sending waves of volunteers to some of the large rewilding projects in Scotland, such as Trees of Life ${ }^{10}$.

In 2019, another award-winning book Wilding: The Return of Nature to a British Farm, by Isabella Tree, was published. The book tells the story of the 'Knepp experiment' - a pioneering rewilding project in West Sussex, using free-roaming grazing animals to create new habitats for wildlife on the site of an exhausted (and financially unsustainable) farm. From successes found in various rewilding projects that re-introduced herbivores instead of carnivores as the keystone species, Tree boldly suggests that the original habitat of the world

\footnotetext{
${ }^{10}$ My knowledge on his influence on such volunteers came from one such person who happens to be a friend.
} 
may be open pasture dominated by herbivores as well as the occasional trees and woodlands, instead of the closed canopy forest as previously agreed by scientists. Although such proposition is not the main argument of the book, its implication could be fundamental, since it is imagining a different wilderness and ancestral landscape of the human race!

By now rewilding has attracted activists. In 2019, the UK-wide environmental protests organised by Extinction Rebellion claimed that 'the act of rewilding is Rebellion' while sending their messages out loudly with their waves of events and occupations ${ }^{11}$. The popularity of Extinction Rebellion is alarming since the campaign rests on the foundation of an apocalypse view towards our future --- the word 'extinction' clearly indicates that. However noble and empowered the ER campaigners may feel, their messages may deepen the gulf between nature and culture, placing nature as a victim external of human society while equalising climate change as 'climate breakdown'12.

Meanwhile, citizen rewilders start to appear, who vow to leave their gardens to nothing but nature. When interviewed why, one such rewilder remarked that 'we have done so much in controlling nature. It is somehow really pleasing to let go. A wildflower meadow seems to be so much more attractive. ${ }^{13}$ Coming from a grassroot angle, such comments clearly demonstrate the attraction of 'wilderness' and 'freedom', however tamed they may be. They also demonstrate that the criticism towards a human against nature binary have reached the general citizens by now, instead of staying in the intellectual and scientific fields.

But of course, this citizen rewilder is fortunate enough to own some land to experiment. And his first action is to repair his boundary walls. Indeed, the boundary can be the first sign implying the contested social, political and ecological stances of such constructed and designed wilderness. Most rewilding projects begin with putting up a fence. Inside of the fence there is wilderness while outside of the fence there is not. Many projects also insist on re-introducing native species. For example, in Isabelle Tree's farm, all the herbivores are

\footnotetext{
${ }^{11}$ The slogan can still be seen on their website: https://rebellion.earth/event/extinction-rebellion-rewilding/ (accessed on the $1^{\text {st }}$ June 2020.)

12 The term 'climate breakdown' is featured on Extinction Rebellion's homepage: https://extinctionrebellion.uk/the-truth/. (accessed on the $10^{\text {th }}$ June 2020.)
}

${ }^{13}$ I conducted the oral interview with the citizen rewilder on the $15^{\text {th }}$ April 2020 in West Yorkshire, UK. 
carefully selected British breeds. Is the contemporary ecology a cosmopolitan one resulted from the constant movements of people and other species? Or is it a national one? The answer for this is far complex than ecology alone ${ }^{14}$. As Tree (2019) writes, to rewild her farm was seen by her neighbouring farmers as a betrayal of the very English way of life. This brings out the question of landscape and national identity. After all, John Constable's The Hey Wain is still one of the most famous of English landscape paintings, depicting an familiar farming landscape of a cottage, a small river, a horse-drawn wagon and a cultivated field. A completely tamed and domestic landscape, just the opposite to a wild one. If such pastoral landscape still represents the quintessential England, however mythic it may be, then it is no wonder that even the re-introduction of beavers to some English woodland can spark controversy ${ }^{15}$.

With these case studies, it is clear that rewilding and the image of the wilderness are vastly contested areas. As an artist concerned with both the physical landscapes and its representation, I am particularly interested in the term 're', since it indicates a baseline in the past. Was there ever a pristine wilderness --- the first nature untouched by human beings? Of course, since we were not there at the time, the 'pure' wilderness can only be an imagination. As powerfully argued by Maris (2011), the idea of a pristine nature is in fact a recent cultural construction, rooted in the European romanticism but amplified by influential American naturalists such as Henry David Thoreau and John Muir. Maris then goes on to provide case studies subverting the slightest possible existence of any pristine nature left in the contemporary landscape before examining how problematic rewilding can be, in both theoretical and practical senses. Maris concludes that the world we live in is in fact a post-

\footnotetext{
${ }^{14}$ A critical discussion on the hybridity of contemporary ecology and the metropolis can be seen in the essay Entering Cosmopolis: Crossingover, Hybridity, Conciliation and the Intercultural City Ecosystem by Julian
} Agyeman, published in Minding Nature _ v7n1_January 2014.

15 An example of the beaver controversy can be read in The Guardian essay It is strange to see the British struggling with the beaver: why is rewilding so controversial, by Patrick Barkham, published on 3 July 2017. The weblink: https://www.theguardian.com/environment/2017/jul/01/rewilding-conservation-ecology-nationaltrust. Accessed on 5 May 2020. ) Similar concerns were raised during my interview with the Forestry England ecologist Cath Bashforth on the 10 June 2019. Bashforth was responsible for re-introducing a pair of beavers into Cropton Forest near Pickering in Yorkshire. Admitting that such action could be seen as 'rewilding', Bashforth preferred not to use the word so the local farmers would not be upset. Farming and rewilding would not go together, according to the local farmers. 
wild world and proposes that the world is now our rambunctious garden to manage and to appreciate.

Geographers Castree and Braun (1998) also state that nature, in both material and semiotical senses, is completely constructed by culture. If there was ever a first nature, then this first nature has now been entirely replaced by landscapes that are made to appear natural or with natural icons. They propose that instead of the word 'nature', we should use 'social nature' as a theoretical baseline which firmly places nature as part of our cultural domain.

Personal reflection on my investigation towards rewilding agrees with the writers above in that our world is a post-wild one and that our nature is a social nature. Such understanding points to a more philosophical question on nature's relationship to us. Clearly, in the postwild world, nature cannot be seen as an existence external to human society. There is no pristine nature untouched by humans. Neither can nature be seen merely as a victim, damaged and to be saved solely by $\mathrm{us}^{16}$. In short, there is no binary between nature and culture. Within this more holistic and more complex social nature environment, the neowilderness constructed by many rewilding and conservation projects can a powerful case study for landscape artists who wish to critically and pictorially examine our current positions within and perceptions of nature. The next section of this paper will provide a brief overview on landscape aesthetic traditions, with contemporary photography as the emphasis. Instead of visual techniques, my attention will be geared towards the philosophical stances manifested by the aesthetics applied in the images. Rather than a conclusion, the section can be seen as an anticipation of a more systematic exploration on how the neo-wilderness has been and can be explored by contemporary landscape photographers.

\footnotetext{
${ }^{16}$ I am aware that an inclusive 'us' is problematic in addressing all human societies with diverse altitudes to and histories with nature. Therefore the 'us' here mainly refers to developed countries founded on scientific and technological advancements, such as countries in western Europe, North America, East Asia and Australia.
} 


\section{Part III: Ways of Seeing}

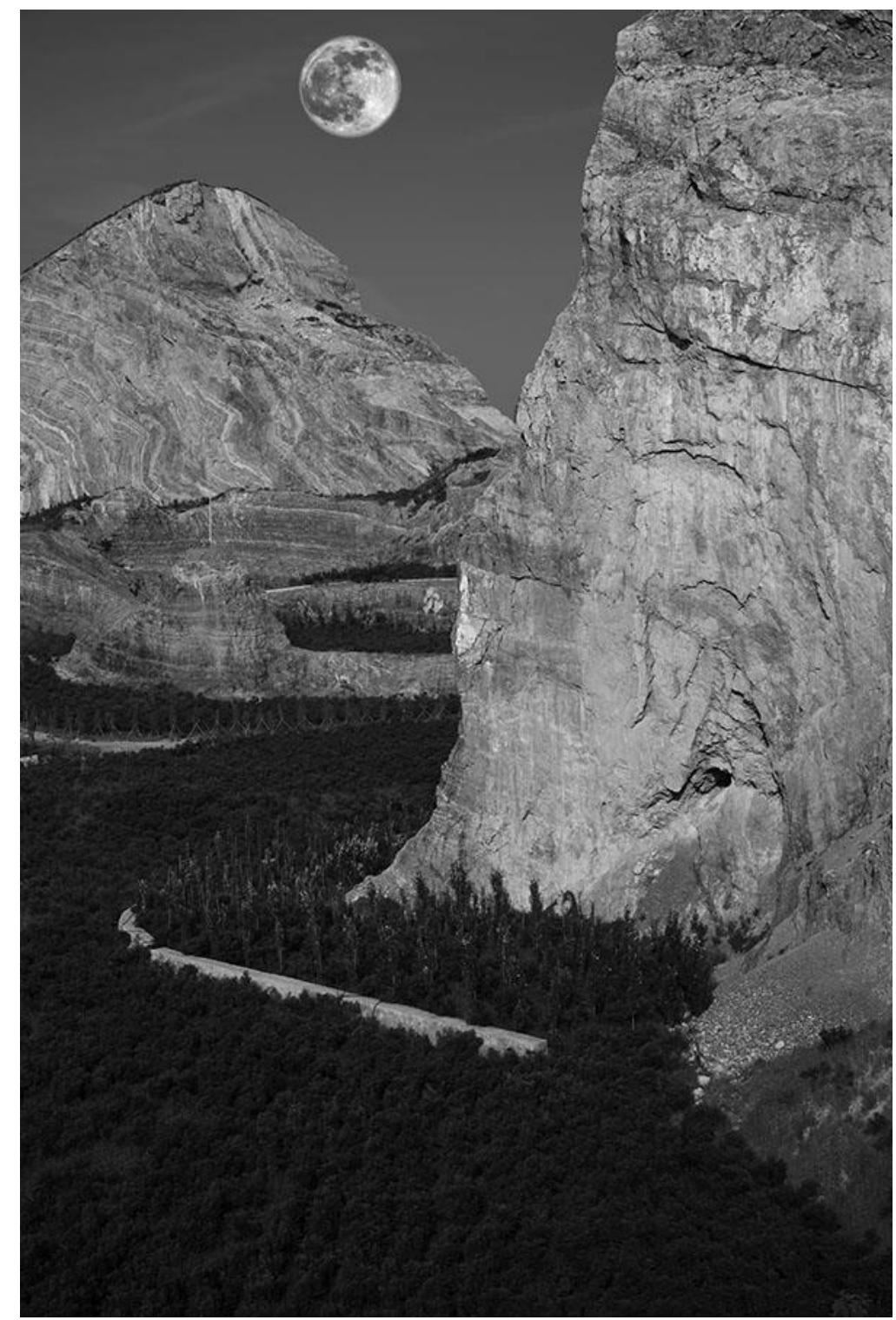

Plate 5 Dongbu Quarry Re-naturalisation Project, Sanhe, Hebei Province, China, 2019. CYan Wang Preston

Nature has been pictured in many different ways, from the imagined to the scientific, from the macro to the micro, from the poetic, to the spiritual and the political. Landscape imagery occupies a particular place within human depiction of nature, visually representing our perceived relationship to nature in its indefinitely contested conditions. Images reflect visions, while ways of seeing are bound within our cultural, social and political context. From a collective and historical perspective, the aesthetic traditions of landscape imagery largely influence the maker and consumer of landscapes from both philosophical and visual ways. 
Wilderness, pristine or engineered, is one extreme state of nature, imagined and constructed by culture.

In the West, landscape became a genre of art during the historical era when industrialisation and urbanisation began to transform a traditional way of life. During this modernising period, land and nature became private properties, commodities, recourses and subjects of scientific enquiry. A separation and distance from nature became large enough to provide the foundation for aesthetic reflection, in which nature was viewed as an external reality from human culture (Wells, 2011; Clark, 1976; Cosgrove, 1998). The foundation of landscape aesthetics was articulated by Burke (1968) in the eighteenth century, who placed landscapes into two groups: the domesticated and possessable nature as small, pleasing and containable -- the beautiful; and the wild nature that has the power to destroy us---the sublime. Burke's nature exists in binary: it is either a beautiful homeland, or an uncivilised wilderness threatening our survival. The wilderness at the time is more an imagined one to be conquered or to be gazed up in a mist, as how it is depicted in Wanderer above the Sea of Fog by Caspar David Friedrich in the early nineteenth century. A wilderness to preserve and to engineer certainly was not in either Burke or Friedrich's consideration. The beautiful and the sublime, as landscape aesthetic traditions, continue to be applicable now, yet how they can relate to the neo-wilderness remains to be seen.

Landscape photography is closely connected to such aesthetic traditions, but a photographic vision of nature had to wait until the media's technical capacity reached certain maturity (for example, early photographic materials in the nineteenth century could not record clouds. The resulted images therefore lacked a crucial element that could contribute significantly towards the emotional impact of a landscape view). After early generations of photographers who operated in the context of the American Gold Rush, the western colonisation and modernisation, Ansel Adams was possibly one of the most influential photographers who firmly placed the vivid image of a pristine wilderness into the eyes of the general public. Interestingly, by then very little wilderness was left in nature. That such pristine nature is in fact highly political and contested has been explored by many subsequent artists, such as Stephen Shore (1982) and Joel Sternfeld (1987). The fact remains that the world of moonrises, rocks, cliffs, clouds, streams, waterfalls and light rays, depicted with perfect tonal ranges, harmonised compositions and dramatized skies, and crucially, without any signs of human existence, has indefinitely and visually constructed an (American) wilderness to us. 
For Adams (2006), such wilderness has spiritual power and strong emotional impacts, and it deserves to be protected. His images define beauty of a wilderness that is not only in the physical landscape, but also in a Black\&White photographic print. Yet the wilderness he depicts is contained within the stable photographic frame and protected by the National Park regulations. Its pristine quality only exists within the photographic print as an illusion instead of a fact (for example, Yosemite Valley was already inhabited by Indian tribes before its discovery by white men. Even when Adams photographed it, it was already a National Park full of tourists.)

The question is, what would it mean if the neo-wilderness is depicted in this established visual language of the pristine wilderness? This new nature is engineered, not by nature as imagined, but by us. And it is often built on some of the least pristine land: the exhausted farms, mines and quarries. Yet it is based, or at least inspired by, an image of the first nature, the pristine wilderness as depicted by Adams. An early test as my attempt to ask this question pictorially can be seen in Plate 5. The photograph depicts a large-scale quarry in China that has recently been re-naturalised. The visual style (high-contrast Black\&White image emphasising the steep rock faces and the dark forest) mimics Ansel Adam's iconic image 'Moon and Half Dome' (1960) while the moon is added in post-production.

A 'naturalistic' way of portraying nature has also been in place within landscape aesthetic traditions, even though the definition of 'naturalistic' is diverse and contested ${ }^{17}$. In contemporary photography, the 1975 exhibition New Topographics: Photographs of A Manaltered Landscape firmly established the topographic and cerebral observation as the chosen aesthetic for the environmentally aware photography practice that has flourished since then (Salvesen and Nordstrom, 2009; Foster-Rice and Rohrbach, 2013) ${ }^{18}$. The contribution made

\footnotetext{
${ }^{17}$ For example, for John Constable, the 'naturalistic' landscapes imply a naturalised social order and a traditional English farming life (Helsinger, 1989). For many photographers in the nineteenth century, the camera's mechanism represented how human eyes saw the world. Therefore, the photographs represented 'natural' visions (Taylor, 2006).

${ }^{18}$ New Topographics: Photographs of A Man-altered Landscape was curated by William Jenkins and staged at the International Museum of Photography at the George Eastman House (Rochester, New York), and remained open to the public from October 1975 until February 1976. It featured ten artists work: Robert Adams, Lewis Baltz, Bernd and Hilla Becher, Joe Deal, Frank Gohlke, Nicholas Nixon, John Schott, Stephen Shore, and Henry Wessel. The exhibition has been hugely influential in the field of landscape photography and has been seen as radical turning point for the media from depicting a pristine, romantic landscape to a land altered by industrial and urban developments.
} 
by such photography towards raising awareness of the global environmental issues cannot be overstated. However, it is my intention here to examine how nature is positioned towards culture by the New Topographics exhibition. I will do so from analysing its title first.

Similar to issues around the term 'rewilding', the term 'man-altered landscapes' indicates that there was a pre-existing landscape that was not altered---a pristine landscape. Next is the word 'man'. Although it is commonly used as a synonym to 'humankind' instead of being specific to one sex, it does invite questions on who exactly this 'man' is. Placing it within the North American context, a pristine wilderness, such as the Yellowstone National Park, is often defined as the state before it was discovered by white men (Maris, 2011; Muir, 2019). This in turn can lead to investigation towards issues around race, western colonisation and the preservation of the wilderness while suggesting that contemporary conversation may carry legacies of colonialism or imperialism (Büscher, 2010). Finally, the term 'topographics' is also problematic, since it subtlety replaces an artistic impression (subjective photographs) with a scientific truth (maps). And the naturalised authority of the latter is no less mythic, as argued elsewhere by geographers such as Cosgrove (1999).

Admittedly, it is no easy task to produce an inclusive yet inviting title for an exhibition that showcased works made by ten different artists with diverse concerns (Jenkins, 1975). But the general environmental stance of the participating artists and the curator William Jenkins is unified in this title, indicating that collectively, they tended to believe that there was a pristine nature and this nature was altered by human beings (mostly from the developed western countries). Perhaps it is not an overstatement to also point out that, the exhibition tended to place nature and culture in binary---while nature and wilderness were good, culture, particularly industries, mines and property developments, was evil.

Robert Adams' work can be used here as an example. One of the most influential photographers featured in the New Topographics exhibition, Adams spent his entire career defending the American West and its natural environment while criticising human development of it. In his essay 'Truth and Landscape' (Adams, 1996:19), he compared the experience of walking in the city as 'dislocation and potential dread' with 'the memories of a better place', located in the remote wilderness of Lapland. In another essay 'Photographing Evil', he referred 'evil' as the strip mines and the pollution caused by them (Adams, 1996). In many of his photographic projects, he condemned deforestation and nuclear power stations, 
while tirelessly celebrating the beauty of a vernacular life and nature in the vast American West.

Robert Adams sees nature and wilderness with superior values over culture and particularly, industry. Although his political stance is clear, his images do not impose such view. His photographs are intimate, lyrical, small in physical scale. They are consistent to the New Topographics exhibition's aesthetic preference, in which a more observational and cerebral response is invited. They invite a shared appreciation of nature and our homeland with it.

Following the environmental awakening encouraged by exhibitions such as the New Topographics and the increasing public concerns towards the Climate Change, a new landscape aesthetic - the toxic sublime, has been established in recent years. Enlarging the gulf between nature and culture while elevating the 'topographic' view, the toxic sublime is defined by scholars such as Peeles (2011) as 'the tensions that arise from recognising the toxicity of a place, object or situation, while simultaneously appreciating its mystery, magnificence and ability of inspire awe'. A leading photographer who developed the toxic sublime is Edward Burtynsky. Different from the pristine landscapes portrayed by Ansel Adams or the nature around the homeland in the American West portrayed by Robert Adams, the subject matter of Burtynsky's is firmly on humanity's transformation of the natural environment, such as mines, quarries, factories, dams, cities and recycling centres. Burtynsky's use of the breath-taking scale, the seductive colour palette and near-abstract patterns produces large-scale photographs that are often aesthetically astonishing and numbing. They certainly invite a feeling of awe and a troubled experience of the sublime. Different from the original source of the sublime experience argued by Burke - the overpowering nature, the source of this toxic sublime is human beings. We made such landscapes of toxicity.

Although the pictorial styles and subject matters differ between the three generations of landscape photographers who are environmentally concerned, I would argue that their philosophical positioning towards nature is consistent. They all believe in a pristine nature independent from human existence, and they all placed culture and nature in binary. As Burtynsky (2012) explained, 'I'm always interested in how humans shape the landscape. All 
my work is really about the pristine landscape being pushed back as a result of the expanding human footprint. 19

The above photographers cannot represent the full spectrum of environmental photography based on landscape depiction. But their widespread influence certainly demonstrates that there has been a strong tendency towards the dualism between nature and culture. The myth of a pristine nature persists, and it is impacting our lives from policy making to ecological projects and to arts. Looking back towards the historical context when western landscape paintings originated, and the recent social-political context when landscape photography is increasingly active towards shaping an environmentally aware visual culture, can I suggest that the genre, in its traditional format and aesthetics, is somewhat doomed in its ability to downplay the nature-culture dualism? Afterall, the development of landscape aesthetics goes parallel to the supremacy of science, modernisation and the western world. The media employs the liner perspective centred around the camera, the eye and the vision, which can be compared to a human-centred viewpoint and a modern sensorial hierarchy. As stated by Cosgrove:

The conventional emphasis on the visual and the visible in landscape forms and expressions is a logical outcome of its conceptual and historical evolution in the West. Many of the research techniques developed in the geographical study of landscape, from field work or iconographic interpretation, maintain the focus on sight, vision and image.

Cosgrove (2002: 265)

It is way beyond this paper's scope to critically examine some of the shared ideologies around science, technology and the single viewpoint of the camera. But other directions of investigation can be suggested, which may be more promising in finding gazes and aesthetics capable of providing a less binary vision. For example, does a feminine gaze have a tendency to be 'with' the land instead of 'above' the land? Or, might the landscape traditions from the colonised, such as the American Indians or the Australian Aboriginals, provide a more immersive vision towards nature and us? What about drawing inspirations from folklores and religions that still insist on a fearful and respectful altitude towards nature? For example, what does it mean if roadside shines dedicated to the Earth God (Tu di Miao), so commonly

\footnotetext{
${ }^{19}$ This quote is taken from the exhibition brochure for Burtynsky's Monegros-Dryland Farming, held at the Flowers Gallery in London from 23 May to 23 June 2012.
} 
seen in many Chinese towns and cities, are brought into western cities or rewilding sites? Might the 'clash' between the scientific and the mythic, the west and the non-west, the empowered and the depowered, provide a fertile ground for debates and discussions?

The landscape tradition in China, Shanshui, can serve as a new departure point for this investigation. If nature is considered more as an external reality in western landscape traditions, then in Shanshui, nature is an inclusive imagination. There is no such thing as 'the pristine wilderness in Shanshui. A Shanshui's world is always a human world, while the wilderness, by definition, is uninhabited by human beings. In one way, the English word, 'wilderness' can relate to many Chinese words: ye wai, huang ye, ye man, all of which have negative undertone as uncivilised and unregulated. Perhaps, there is only ye qu, that points towards the pleasure of the wilderness. Yet such pleasure is only to be dipped in, not to be indulged upon, just like the fenced off wilderness that we are trying to build now. Could the ideal and civilised world of Shanshui at least be a reference to understand contemporary wilderness? Before we test the idea, caution is needed. In the eyes of contemporary artists who are hold critical views towards industrialisation and urbanisation, the pictorial world of Shanshui are often mistaken as the environmental reality of traditional China. For example, as one of the leading artists using Shanshui as the aesthetic foundation and historical reference, Yang Yongliang (2011) states that the 'ancient Chinese expressed their appreciation of nature and feeling for it by painting the Landscape. In contrast, I make my landscape to criticize the realities in my eyes'.

Yet historians have discovered that vast scale environmental interventions, such as deforestation and farming, were carried out in traditional China. By the eighteenth-century China's environmental degradation was worse than Western Europe, which was going through the Industrial Revolution (Elvin, 2006). Such research shows that Shanshui paintings portray a simplified and idealised vision of the physical and political world that is otherwise decisively complex and contested. If a criticism of the modern China's environmental reality is based on a mythicised past, then such criticism is built on questionable ground. But China remains a crucial link in human's reconciliation with nature. Let's just imagine --- what kind of humanity is required, if one day we decide to 'free' the Yangtze River and to remove all of its over thirty hydro-electric dams? And how may we picture that 'freer' and 'wilder' river? 
To summarise, this paper started with a critical review of my photographic project Forest (2018) and contextualised the project within the contemporary discussion on the commodification of nature in an urban environment. The project began by placing trees (nature) and people (the city) at confrontation but progressed to a moment when an urban ecology began to form with its transplanted trees, people and new concrete infrastructure. In one way, the project anticipates the arguments made by geographers such as Gandy (2020) that the urban can also be seen as habitat, an ecological system with its own particular conditions, just as a forest or a wetland.

The notion of a construction nature was then extended from the urban trees to the neowilderness -the wild landscape constructed and preserved by rewilding projects in China and beyond. Drawing empirical and theoretical studies, the politics and ideologies of such neowilderness were discussed before a conclusion was made: that our world is a post-wild one and our nature is a social nature. Within such understanding, rewilding and the neowilderness constructed by it can serve as a catalyst in critically understanding our perceptions of nature now, which may avoid a prevalent, dualism view towards nature and culture.

The final section of the paper examined some of the established landscape aesthetics and the representative photographers' work. It discovered that a view of a pristine nature external of human existence is still widely held in the field of landscape photography with environmental concerns. Meanwhile, possible limitation of the media is detected from its shared ideology that places the human vision at the centre of an enquiry and nature as an external subject matter. The paper thus suggested other ways of seeing, such as the aesthetic of Chinese traditional landscape paintings, that may be better suited to de-colonise the conventional western landscape view. In the anticipation for a more in-depth investigation of such decolonised view, the paper will conclude here by asking new questions: how do our established landscape aesthetics cope with the neo-wilderness? Can they cope? Is there another way (or ways) of seeing that can better portray our post-wild world and social nature with complexities instead of binaries, hopes instead apocalypses? These can be questions for a new generation of landscape photographers, Chinese or not. 


\section{Glossary:}

Bai 白族

Daqing Tree 大青树

Da Yu Zhi Shui 大禹治水

Huang ye 荒野

Long 龙

Li Ming 黎明 (b.1976)

Li Zhaohui 李朝辉 (b.1968)

Tu Di Miao 土地庙

Xiao Xuan'an 肖宣安 (b.1960)

Xi Jinping 习近平 (b.1953)

Yan Changjiang 颜长江 (b.1968)

Yang Yongliang 杨泳梁 (b.1980)

Ye man 野蛮

Ye qu 野趣

Ye wai 野外

Zen Hang 曾翰 (b.1974)

Zhang Kechun 张克纯 (b.1980)

Zhuang Hui 庄辉 (b.1963)

\section{References:}

Adams, A. 2006. Sierra Nevada: The John Muir Trail. New York: Little, Brown and Company

Adams, R. 1996. Beauty in Photography. New York: Aperture.

Bialobrzeski, P. 2009. Lost in Transition. Berlin: Hatje Cantz

Burtynsky, E., Mayer, M., Fischman, T. and Kingwell, M. 2005. Edward Burtynsky: China Göttingen: Steidl. 
Büscher, Bram. 2010. "Derivative Nature: Interrogating the Value of Conservation in 'Boundless Southern Africa.'” In Third World Quarterly 31 (2): 259-76.

https://doi.org/10.1080/01436591003711983

Braun, B. and Castree, N. (ed) 1998. Remaking Reality: Nature of the Millennium. New York: Routledge.

Burke, E. 1968. A Philosophical Enquiry into the Origin of our Ideas of the Sublime and Beautiful .London: Routledge and Kegan Paul.

Clark, K. 1976. Landscape into Art (New Edition). London: John Murray (Publishers) Ltd.

Cosgrove, D. 1998. Social Formation and Symbolic Landscapes. Madison: University of Wisconsin Press.

Cosgrove, D. 2002. 'Landscape and the European Sense of Sight', in Anderson, K., Domosh, M. and Pile, S. (eds) Handbook of Cultural Geography. London, Thousand Oaks, New Delhi: Sage Publications.

Dukes, T. and Preston, Y.W. 2020. 'On Forest' in Journal of International Photography, Volume One, 2020, P.37-47.

Elvin, M. 2006. The Retreat of the Elephants: An Environmental History of China. New Haven: Yale University Press.

Foster-Rice, G. and Rohrbach, J. (eds) 2013. Reframing the New Topographics. Chicago: The Centre for American Places at Columbia College Chicago.

Gandy, M. 2018. Cities in deep time, (City, 22:1, 96-105, DOI:

$10.1080 / 13604813.2018 .1434289)$

Gandy, M. 2017. Natura Urbana: The Brachen of Berlin. Documentary film, released by Rethinking Urban Nature, a research project at the University of Cambridge. 
Gandy, M. and Jasper, S. (eds) 2020. The Botanical City. Berlin: Jovis Verlag.

Hesinger, E. 1989. The Making of a National Painter, in Critical Inquiry, Nov.15, No. 2 pp.253-279. Chicago: The University of Chicago Press.

https://www.jstor.org/stable/1343585.

International Museum of Photography. 1985. New Topographics. Photographs of a ManAltered Landscape. Robert Adams, Lewis Baltz, Bernd and Hilla Becher, Joe Deal, Frank Gohlke, Nicholas Nixon, John Schott, Stephen Shore, Henry Wessel, Jr. Rochester: International Museum of Photography at George Eastman House.

Jackson, J. B. 1984. Discovering the Vernacular Landscape. New Haven and London: Yale University Press.

Jiang, Jiehong. 2015. An Era without Memories: Chinese Contemporary Photography on Urban Transformation. London: Thames and Hudson Ltd.

Kander, N. and Tchang, J. P. 2010. Nadav Kander: Yangtze - The Long River. Berlin: Hatje Cantz.

Katz, C. 1998. "Whose Nature, Whose Culture? Private Productions of Space and the 'Preservation' of Nature." In Remaking Reality: Nature of the Millennium, edited by Braun, B. and Castree, N. New York: Routledge.

Kuyas, F. 2009. Chongqing - City of Ambition. Amsterdam: Schilt Publishing.

Lewis, Mark E. 2006. The Flood Myths of Early China. New York: State of University of New York Press.

Maris, E. 2011. Rambunctious Garden: Saving Nature in a Post-Wild World. London: Bloomsbury.

Martinsson, T. 2015. Arctic Views: Passages in Time. Stockholm: Art and Theory Publishing. 
Monbiot, G. 2013. Feral: rewilding the land, sea and human life. London: Penguin Books.

Muir, J. 2019. The Wilderness Essays. Online: Madison \& Adams Press

Peeles, J. 'Toxic Sublime: Imaging Contaminated Landscapes' in Environmental Communication: A Journal of Nature and Culture, 2011, 5:4, pp. 373-392

Salvesen, B. and Nordstrom, A. 2009. New Topographics: Roberts Adams. Lewis Baltz. Bernd and Hilla Becher. Joe Deal. Frank Gohlke. Nicholas Nixon. John Schott. Stephen Shore. Henry Wessel, Jr. Göttingen: Steidl.

Preston, Y.W. 2018. Forest. Berlin: Hatje Cantz.

Schama, S. 2004. Landscape and Memory. London: Harper Perennial.

Soule, M.E. and Peters, R.L. 2014. Collected Papers of Michael E. Soule: Early Years in Modern Conservation Biology. Washington, Covelo, London: Island Press.

Shore, S. 1982. Uncommon Places. New York: Aperture.

Sternfeld, J. 1987. American Prospects. New York: Times Books.

Taylor, J. 1986. P.H. Emerson: life and landscape, art \& photography in East Anglia 18851900. Norwich: Sainsbury Centre for Visual Arts.

Tree, I. 2019. Wilding: The Return of Nature to a British Farm. London: Picador.

Wolf, M. 2012. Architecture of Density. Berlin: Peperoni Books.

Wells, L. 2011. Land Matters. London: I. B. Tauris \&Co Ltd.

Wilson, E.O. 1990. Biophilia. (New edition). Cambridge: Harvard University Press.

Wu, Hung. 2008. Displacement: The Three Gorges Dam and Contemporary Chinese Art. 
Chicago: Smart Museum of Art.

Yang, Yongliang. 2011. Yang Yongliang. Luxemburg: Arendt \& Medernach.

Zhang, Kechun. 2014. The Yellow River. Beijing: Jiazazhi Press. 